\title{
Characterization of blast resistance related protein domains in wheat for molecular marker development
}

\author{
M. Thoihidul Islam, Mohammad Rashid Arif and ${ }^{\otimes}$ Arif Hasan Khan Robin \\ Department of Genetics and Plant Breeding, Bangladesh Agricultural University, Mymensingh 02202, Bangladesh
}

\begin{tabular}{l} 
ARTICLE INFO OPENOACcess \\
\hline Article history: \\
Received : 24 January 2019 \\
Accepted : 16 May 2019 \\
Published: 30 June 2019 \\
\hline
\end{tabular}

Keywords:

Wheat, blast disease, resistance domain, molecular markers

Correspondence:

Arif Hasan Khan Robin

$凶$ : gpb21bau@bau.edu.bd

\begin{abstract}
Wheat blast is a devastating disease which is baffling scientists from its inception. This study characterized the blast resistance related protein domains with a view to develop molecular markers to identify resistant wheat genotypes against Blast fungus Magnaporthe oryzae. A genome browse analysis detected that the candidate resistance gene against blast could be located in several different chromosomes. An in silico analysis was collected with fifty nucleotide-binding site leucine-rich repeat (NBS-LRR), leucine-rich repeat (LRR), pathogenesis and resistance protein-encoding accessions on the basis of the previous resistance report. The phylogenetic tree of those putative resistance accessions, bearing resistance related protein-encoding domains, showed that an NBS-LRR accession JP957107.1 has $67 \%$ similarity with the disease resistance protein domain encoding accession of Brazilian resistant cultivar Thatcher. By contrast, the rice blast resistance Pita gene has $72 \%$ similarity with 18 pathogenesis protein domain encoding accessions. Among putative protein domains, disease resistance protein of Thatcher has 78\% similarity with two NBS-LRR protein domains AAZ99757.1 and AAZ99757.1. Eighteen microsatellite markers were designed from eighteen putative NBS-LRR protein encoding accessions along with Piz3 marker. The 19 markers were unable to separate resistant and susceptible genotypes. Diffused versus conspicuous bands indicated either presence of insertion/deletion (InDel) or single nucleotide polymorphism (SNP) among wheat genotypes. Detection of InDel or SNP markers is a subject of further investigation. Additional markers are needed to be designed using new NBS-LRR, pathogenesis, coiled-coil (CC), translocated intimin receptor (TIR) resistance protein encoding accessions to find out markers specific for blast resistance.
\end{abstract}

Copyright:

(c) (i)

(O2019 by authors and BAURES. This work is licensed under the Creative Commons Attribution International License (CC By 4.0).

\section{Introduction}

Blast is a serious disease of major cereal producing poaceae family members including wheat and rice. In Latin, blast is called as "Brusone" (Couch and Kohn, 2002). Magnaporthe oryzae pathotype Triticum fungus is accountable for blast disease in wheat (Malaker et al., 2016). The first occurrence of wheat blast was noticed in 1985 and Parana province of Brazil was the hotspot (Igarashi, 1986). In February 2016, Bangladesh became the first wheat blast affected South-Asian country (Callaway, 2016). For wheat blast disease crop production can be dwindled from $40 \%$ to $100 \%$ (Kohli et al., 2011; Goulart and Paiva, 1992). After first blast outbreak in 1985 in Brazil, scientists started searching for sources of resistance to resist this terrifying disease but the way was much harder (Urashima et al., 2004; Prestes et al., 2007; Cruz et al., 2010, 2016). The resistance against blast pathogen depends on $\mathrm{R}$ gene. The main problem based on $\mathrm{R}$ gene resistance is "breakdown of resistance" due to the high level of pathogenic variation within blast pathogen (Kiyosawa, 1982; Leach et al., 2001). Global warming is one of the significant reasons for dissemination and development of blast disease (Kohli et al., 2011).
Most of the disease resistance genes in plants encode nucleotide-binding site leucine-rich repeat (NBS-LRR) proteins (Mchale et al., 2006, Laila et al., 2019). Hypersensitive reaction to a pathogen triggered by pathogenesis related protein which is one of the most efficient defense mechanism (Stintzi et al., 1993). In case of rice blast, it has found that NBS-LRR protein domain has role in resistance and specifically nineteen blast resistant genes encode NBS-LRR protein domain (Jiang et al., 2012). So it's urgent to search and characterize protein domains related with blast resistance. The study was conducted to explore the structure and interaction pattern of resistance related domains including NBS-LRR, leucine-rich repeat (LRR), coiled-coil (CC), translocated intimin receptor (TIR), pathogenesis, and resistance protein domain for developing microsatellite markers to identify genotypes resistant to wheat blast.

\section{Materials and Methods}

\section{In silico analysis}

Desired list of protein-encoding domains were collected from NCBI, Ensembl Plants and Gramene databases 
along with their accession numbers (Ware et al., 2002; Pruitt et al., 2006; Bolser et al., 2016; Table 1). For illustration of the accessions with exon-intron and flanking regions the GSDS online software was used (Guo et al., 2007). The BLAST similarity search was conducted to find out syntenic locations of disease resistance protein-encoding accession of Thatcher genotype (GenBank accession: KY064065.1) and Pita gene (GenBank accession: AY196754.1) (Bolser et al., 2016). Thatcher is a blast resistant Brazilian wheat genotype containing two R genes Rmg2 and Rmg3 (Zhan et al., 2007). After that, Pita is a rice blast resistant gene. Pita is a monogenic qualitative $\mathrm{R}$ gene which is also known as Rmgl6 found in Japonica rice. Previously from Pita gene, Piz3 marker was developed and utilized against rice blast (Imam et al., 2014). Finally, phylogenetic analysis was performed in online software Phylogeny.fr (Dereeper et al., 2008). "HSP distribution on genome" was obtained for disease resistance proteinencoding accession of Thatcher and Pita through BLAST search.

Table 1. List of retrieved accessions from NCBI with the protein encoding domains

\begin{tabular}{|c|c|c|c|c|c|}
\hline Serial no. & Accession no. & Protein type & Serial no. & Accession no. & Protein type \\
\hline 1 & KY064065.1 & $\begin{array}{l}\text { Disease resistance protein- } \\
\text { encoding }\end{array}$ & 26 & GUOS4176.1 & LRR protein encoding \\
\hline 2 & AY196754.1 & Rice blast resistant & 27 & DQ097959.1 & LRR protein encoding \\
\hline 3 & KX181569.1 & NBS-LRR protein encoding & 28 & AJ606035.1 & LRR protein encoding \\
\hline 4 & DQ128005 & NBS-LRR protein encoding & 29 & HQ541963.1 & Pathogenesis protein encoding \\
\hline 5 & AF320847.1 & NBS-LRR protein encoding & 30 & AY258615.1 & LRR protein encoding \\
\hline 6 & DQ145755 & NBS-LRR protein encoding & 31 & KX673535.1 & Pathogenesis protein encoding \\
\hline 7 & KF810140.1 & NBS-LRR protein encoding & 32 & KX673549.1 & Pathogenesis protein encoding \\
\hline 8 & DQ128021.1 & NBS-LRRprotein encoding & 33 & KX673548.1 & Pathogenesis protein encoding \\
\hline 9 & DQ128020.1 & NBS-LRR protein encoding & 34 & KX673547.1 & Pathogenesis protein encoding \\
\hline 10 & DQ128017.1 & NBS-LRR protein encoding & 35 & KX673546.1 & Pathogenesis protein encoding \\
\hline 11 & DQ128002.1 & NBS-LRR protein encoding & 36 & KX673543.1 & Pathogenesis protein encoding \\
\hline 12 & DQ128000.1 & NBS-LRR protein encoding & 37 & KX673539.1 & Pathogenesis protein encoding \\
\hline 13 & DQ127990.1 & NBS-LRR protein encoding & 38 & KX673538.1 & Pathogenesis protein encoding \\
\hline 14 & DQ120792.1 & NBS-LRR protein encoding & 39 & KX673537.1 & Pathogenesis protein encoding \\
\hline 15 & AY555270.1 & NBS-LRR protein encoding & 40 & KX673536.1 & Pathogenesis protein encoding \\
\hline 16 & AY238935.1 & NBS-LRR protein encoding & 41 & KF196311.1 & Pathogenesis protein encoding \\
\hline 17 & AY212115 & NBS-LRR protein encoding & 42 & HQ700377.1 & Pathogenesis protein encoding \\
\hline 18 & AF525278 & NBS-LRR protein encoding & 43 & HQ541981.1 & Pathogenesis protein encoding \\
\hline 19 & JF957107 & NBS-LRR protein encoding & 44 & HQ541979.1 & Pathogenesis protein encoding \\
\hline 20 & GU356591 & NBS-LRR protein encoding & 45 & HQ541976.1 & Pathogenesis protein encoding \\
\hline 21 & KY784576.1 & LRR protein encoding & 46 & HQ541965.1 & Pathogenesis protein encoding \\
\hline 22 & KX840357.1 & LRR protein encoding & 47 & AY270159.1 & Pathogenesis protein encoding \\
\hline 23 & KC700616.1 & LRR protein encoding & 48 & AY270158.1 & Resistance protein encoding \\
\hline 24 & KC70015.1 & LRR protein encoding & 49 & AY270157.1 & Resistance protein encoding \\
\hline 25 & JN872563.1 & LRR protein encoding & 50 & DQ205351.2 & Resistance protein encoding \\
\hline
\end{tabular}

\section{Marker design}

Eighteen NBS-LRR protein domain encoding accessions were selected from NCBI database to design primers to develop PCR-based markers. Primers were designed using online tool Primer3plus (Table 2). The Primer3plus online tool picked up forward and reverse primers with the product size between 150 and $250 \mathrm{bp}$ and annealing temperature between $58^{\circ} \mathrm{C}$ and $61^{\circ} \mathrm{C}$ (Table 2, Untergasser et al., 2007). Piz3 primer referring Pita gene was collected from Gramene database (Imam et al., 2014). The relevant information of 18 designed markers and $\mathrm{Piz} 3$ microsatellite marker are given in Table 2.

\section{Marker Validation}

Collection of genotypes and extraction of DNA

A total of 18 wheat genotypes belongs to Triticum aestivum were used in this experiment (Table 3). Among those varieties BARI Gom 33 has blast resistance, Bari Gom 31-32 have moderate blast tolerance and Bari Gom 25-30 have susceptibility to blast (DGGW, 2017, Personal Communication, NCD Barma, Director, Bangladesh Wheat and Maize Research Institute). The modified Cetyl Trimethyl Ammonium Bromide (CTAB) mini-prep method was used to extract genomic DNA from the wheat leaves (Zhang et al., 2013). 
Table 2. Details of the designed microsatellite markers (SSRs) for validation

\begin{tabular}{|c|c|c|c|c|c|}
\hline $\begin{array}{c}\text { Primer } \\
\text { Name }\end{array}$ & $\begin{array}{l}\text { GenBank } \\
\text { accession }\end{array}$ & & Sequence $\left(5^{\prime}-3^{\prime}\right)$ & $\begin{array}{c}\text { Annealing } \\
\text { Temp. } \\
\left({ }^{\circ} \mathrm{C}\right)\end{array}$ & $\begin{array}{c}\text { Expected PCR } \\
\text { Product } \\
\text { Size }\end{array}$ \\
\hline M1 & AF525278.1 & $\begin{array}{l}\text { Fwd. } \\
\text { Rev. }\end{array}$ & $\begin{array}{l}\text { TGTCACAATCATGCGACCTT } \\
\text { GCTTGGCCAACTCATTAACC }\end{array}$ & 58 & 167 \\
\hline M2 & DQ145755.1 & $\begin{array}{l}\text { Fwd. } \\
\text { Rev. }\end{array}$ & $\begin{array}{l}\text { AAGGCTCAACTTACCGTGGA } \\
\text { TGTTGTGAGGATCAGCTTGC }\end{array}$ & 58 & 170 \\
\hline M3 & DQ128021.1 & $\begin{array}{l}\text { Fwd. } \\
\text { Rev. }\end{array}$ & $\begin{array}{l}\text { GCGGGGAGAGAGATACAAGA } \\
\text { AGCGAGTCCGACACCTAGAG }\end{array}$ & 58 & 156 \\
\hline M4 & DQ128020.1 & $\begin{array}{l}\text { Fwd. } \\
\text { Rev. }\end{array}$ & $\begin{array}{l}\text { TTGCAGGAGATGTTGTGCTC } \\
\text { GCAACCCTTTTGCTTTGTGT }\end{array}$ & 58 & 233 \\
\hline M5 & DQ128019.1 & $\begin{array}{l}\text { Fwd. } \\
\text { Rev. }\end{array}$ & $\begin{array}{l}\text { GCGCTCTTVTGAAAGGAAATG } \\
\text { GCAACCCTTTTGCTTTGTGT }\end{array}$ & 58 & 222 \\
\hline M6 & DQ128017.1 & $\begin{array}{l}\text { Fwd. } \\
\text { Rev. }\end{array}$ & $\begin{array}{l}\text { AAGCGGTTGTTGCTTGTTTT } \\
\text { CCCCATGACTTAGACGTTCC }\end{array}$ & 58 & 193 \\
\hline M7 & DQ128007.1 & $\begin{array}{l}\text { Fwd. } \\
\text { Rev. }\end{array}$ & $\begin{array}{l}\text { GCAAGCTGATCCTCACAACA } \\
\text { GCCATCCAACTGATGCACTA }\end{array}$ & 58 & 153 \\
\hline M8 & DQ128005 & $\begin{array}{l}\text { Fwd. } \\
\text { Rev. }\end{array}$ & $\begin{array}{l}\text { GCAAGCTGATCCTCACAACA } \\
\text { TACCATTCTGGGAACCAAGC }\end{array}$ & 58 & 171 \\
\hline M9 & DQ128002.1 & $\begin{array}{l}\text { Fwd. } \\
\text { Rev. }\end{array}$ & $\begin{array}{l}\text { CTTTCACCCAACGCCTGTAT } \\
\text { GCGCAATGGATTTTTGAAGT }\end{array}$ & 58 & 189 \\
\hline M10 & DQ128000.1 & $\begin{array}{l}\text { Fwd. } \\
\text { Rev. }\end{array}$ & $\begin{array}{l}\text { TGTGCTTGATGATGTGTGGA } \\
\text { GCTACCCAATGGCTGGAGTA }\end{array}$ & 58 & 157 \\
\hline M11 & DQ127998.1 & $\begin{array}{l}\text { Fwd. } \\
\text { Rev. }\end{array}$ & $\begin{array}{l}\text { GGTACATATCGCCGTGCTCT } \\
\text { TTGGGTGTGCATTGGAGTTA }\end{array}$ & 58 & 190 \\
\hline M12 & DQ127990.1 & $\begin{array}{l}\text { Fwd. } \\
\text { Rev. }\end{array}$ & $\begin{array}{l}\text { AGAGAAGGACAGGGGTGGAT } \\
\text { GCCTTGAAAAACAGCCAAAA }\end{array}$ & 58 & 177 \\
\hline M13 & KF810141.1 & $\begin{array}{l}\text { Fwd. } \\
\text { Rev. }\end{array}$ & $\begin{array}{l}\text { CTGCGTACAAAGACCAGCAA } \\
\text { ATCCTTGGGAAACACAGCAC }\end{array}$ & 58 & 162 \\
\hline M14 & KX181569.1 & $\begin{array}{l}\text { Fwd. } \\
\text { Rev. }\end{array}$ & $\begin{array}{l}\text { ACTCATCCGGTCGTTACCAG } \\
\text { GACACCAGGGTAGGGCAGTA }\end{array}$ & 58 & 150 \\
\hline M15 & DQ120792.1 & $\begin{array}{l}\text { Fwd. } \\
\text { Rev. }\end{array}$ & $\begin{array}{l}\text { AAGCATTTCCAGTTGCTGCT } \\
\text { TCCAGGACAAGGAGATACCG }\end{array}$ & 60 & 170 \\
\hline M16 & JF957107.1 & $\begin{array}{l}\text { Fwd. } \\
\text { Rev. }\end{array}$ & $\begin{array}{l}\text { CAGGTGGGAAAGAAGATCCA } \\
\text { TCCCAACTCCTCGTTTCATC }\end{array}$ & 58 & 236 \\
\hline M17 & KF810140.1 & $\begin{array}{l}\text { Fwd. } \\
\text { Fwd. }\end{array}$ & $\begin{array}{l}\text { GAGTGCAGCAATGTTGGAGA } \\
\text { CCCTTGCATCATCCCTAGAA }\end{array}$ & 58 & 172 \\
\hline M18 & AY238935.1 & $\begin{array}{l}\text { Fwd. } \\
\text { Rev. }\end{array}$ & $\begin{array}{l}\text { ATCGCTGACCATTTTGAAGC } \\
\text { CCTGTAGCTGCTCCCTTTTG }\end{array}$ & 58 & 220 \\
\hline$P i z 3$ & AY196754.1 & $\begin{array}{l}\text { Fwd. } \\
\text { Rev. }\end{array}$ & $\begin{array}{l}\text { AGTCGTGCGATGCGAGGACAGAAAC } \\
\text { GCATTCTCCAACCCTTTTGCATGCAT }\end{array}$ & 62 & 861 \\
\hline
\end{tabular}

Table 3. List of wheat genotypes collected from Bangladesh Agriculture Research Institute (BARI) used to assess resistant and susceptible wheat genotypes against wheat blast disease

\begin{tabular}{ccc}
\hline Sl. No. & Name of the wheat genotypes & Type \\
\hline 1 & BARI Gom 21 & High yielding variety (HYV) \\
2 & BARI Gom 22 & HYV \\
3 & BARI Gom 23 & HYV \\
4 & HARI Gom 24 \\
5 & BARI Gom 25 & HYV \\
6 & BARI Gom 26 & HYV \\
7 & BARI Gom 27 & HYV \\
8 & BARI Gom 28 & HYV \\
9 & BARI Gom 29 & HYV \\
10 & BARI Gom 30 & HYV \\
11 & BARI Gom 31 & HYV \\
12 & BARI Gom 32 & HYV \\
13 & BARI Gom 33 & HYV \\
14 & Honalika & HYV \\
15 & Gourav & HYV \\
16 & Sourav & HYV \\
18 & Aghrani & Landrace \\
\hline
\end{tabular}


PCR amplification and agarose gel electrophoresis Addbio ${ }^{\circledR}$ Taq Master Mix was used to amplify genomic DNA of 18 wheat genotypes. Each $10 \mu \mathrm{l}$ PCR reaction included $1 \mu \mathrm{l}$ DNA, $2 \mu \mathrm{l}$ of each primer, $3.5 \mu \mathrm{l}$ PCR master mix and $3.5 \mu \mathrm{l}$ sterile distilled water. Reactions were pre-incubated for $5 \mathrm{~min}$ at $94^{\circ} \mathrm{C}$ followed by 35 cycles of amplification at $95^{\circ} \mathrm{C}$ for $45 \mathrm{~s}$, $58-62{ }^{\circ} \mathrm{C}$ for $45 \mathrm{~s}$ and $72^{\circ} \mathrm{C}$ for $45 \mathrm{~s}$ in the GeneAtlas thermal cycler (Astec Co. Ltd, South Korea). Electrophoresis of PCR product was done by using $1.5 \%$ agarose.

\section{Results and Discussion}

Putative disease resistance protein encoding accession of Thatcher cultivar and its synteny in wheat genome

The sequence of putative disease resistance protein encoding gene of Thatcher accession is 2739 bp (Pruitt et al., 2006). The disease resistance protein-encoding accession of Thatcher showed best match between 24401845 and 24404427 bp with $99.8 \%$ identity on unknown chromosome of wheat (Bolser et al., 2016).

The paralogs of that resistance protein domain-encoding accession of Thatcher were distributed throughout the wheat genome except 1D, 3A, 4D, 6D and 7D chromosomes indicating that resistance related to wheat blast might be located in any of those chromosomes. But this speculation is a subject of further investigation (Fig. 1).

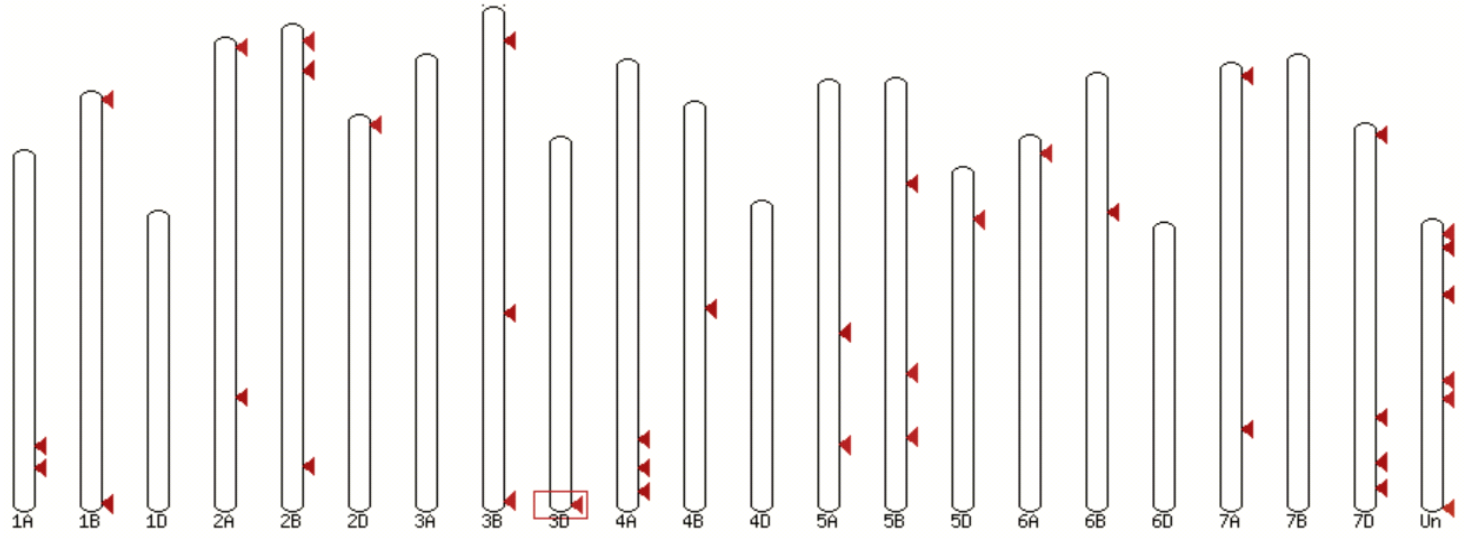

Fig. 1. Distribution of the paralogs of disease resistance accession of Thatcher in the whole genome of wheat. BLAST search was conducted in wheat genome of Ensembl Plants where disease resistance accession of Thatcher was used as reference sequence. Highest number of hits was found in the unknown chromosome of wheat. The paralog of disease resistance accession of Thatcher was completely absent in 1D, 3A, 4D, 6D and 7D chromosomes of wheat.

Putative rice blast resistance gene Pita and its synteny in wheat genome

The total sequence size of the Pita gene was $5113 \mathrm{bp}$ (Ware et al., 2002). The Pita gene showed the best match in the 5A chromosome between 548608286 and 548608336 bp of wheat genome with $90.2 \%$ identity in
5A chromosome of wheat (Bolser et al., 2016). The orthologs of Pita gene were distributed in all chromosomes of wheat genome except for 1A chromosome. The highest frequency of the paralogs was seven and was found in 1D, 4A, 7A, 7B and 7D chromosomes of the wheat genome (Fig. 2).

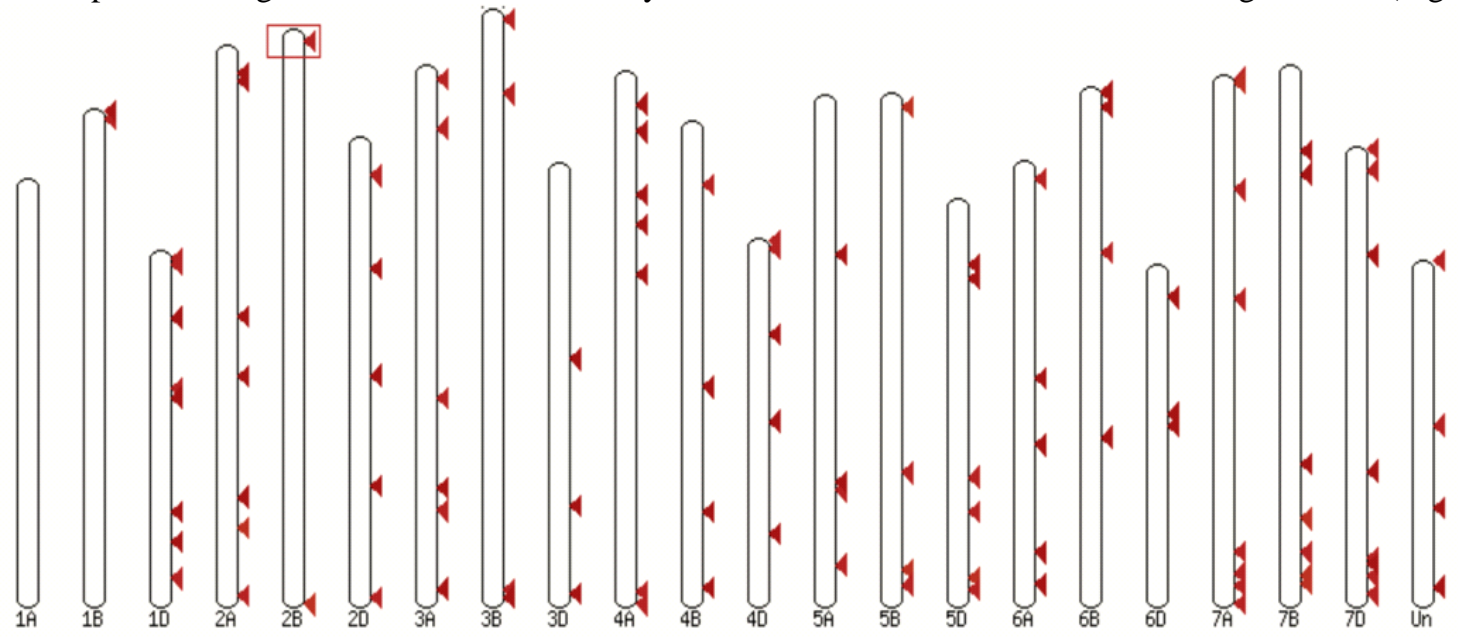

Fig. 2. Distribution of the orthologs of Pita gene in the whole genome of wheat. BLAST search was conducted in wheat genome of Ensembl Plants where Pita gene sequence was used as reference sequence. Highest hits were found in 1D, 4A, 7A, 7B and 7D chromosomes of the wheat genome and totally absent in 1A chromosome. 
Exon-intron distribution of resistance-protein encoding sequences

The smallest NBS-LRR protein coding accession among the fifty selected accessions was DQ128021.1 with 194 bp size and KX181569.1 was the largest NBS-LRR

\section{Legend:}

CDS protein-encoding accession with $3390 \mathrm{bp}$ size. The intron was present in three NBS-LRR protein encoding accession (DQ128005, DQ145755, and KF810140.1) (Fig. 3).

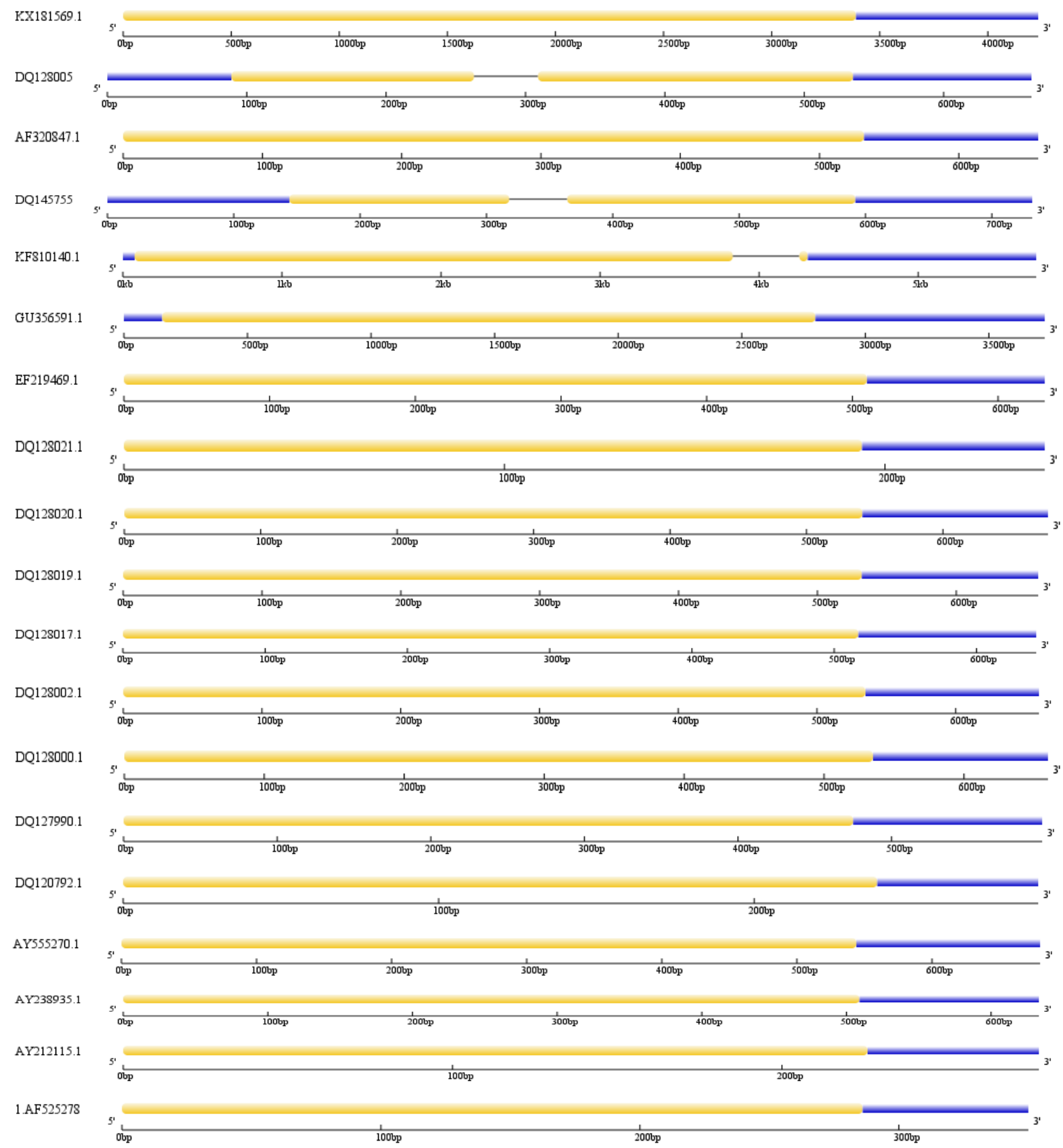

Fig. 3. Exon-intron distribution of accessions encoding NBS-LRR protein domain. GenBank accessions: KX181569.1, DQ128005, AF320847.1, DQ145755, KF810140.1, DQ128021.1, DQ128020.1, DQ128017.1, DQ128002.1, DQ128000.1, DQ127990.1, DQ120792.1, AY555270.1, AY238935.1, AY212115, AF525278

Among eight LRR protein encoding accessions, DQ097959.1 was the smallest and KY784576.1 was the largest. The intronic sequence was absent in eight accessions (Fig. 4).
Among eighteen pathogenesis protein-encoding accessions, AY258615.1 was the smallest with the size of $560 \mathrm{bp}$ and KX673535.1 was the largest pathogenesis protein-encoding accession with the size of $2241 \mathrm{bp}$ (Fig. 5). 
Wheat blast resistance protein domain

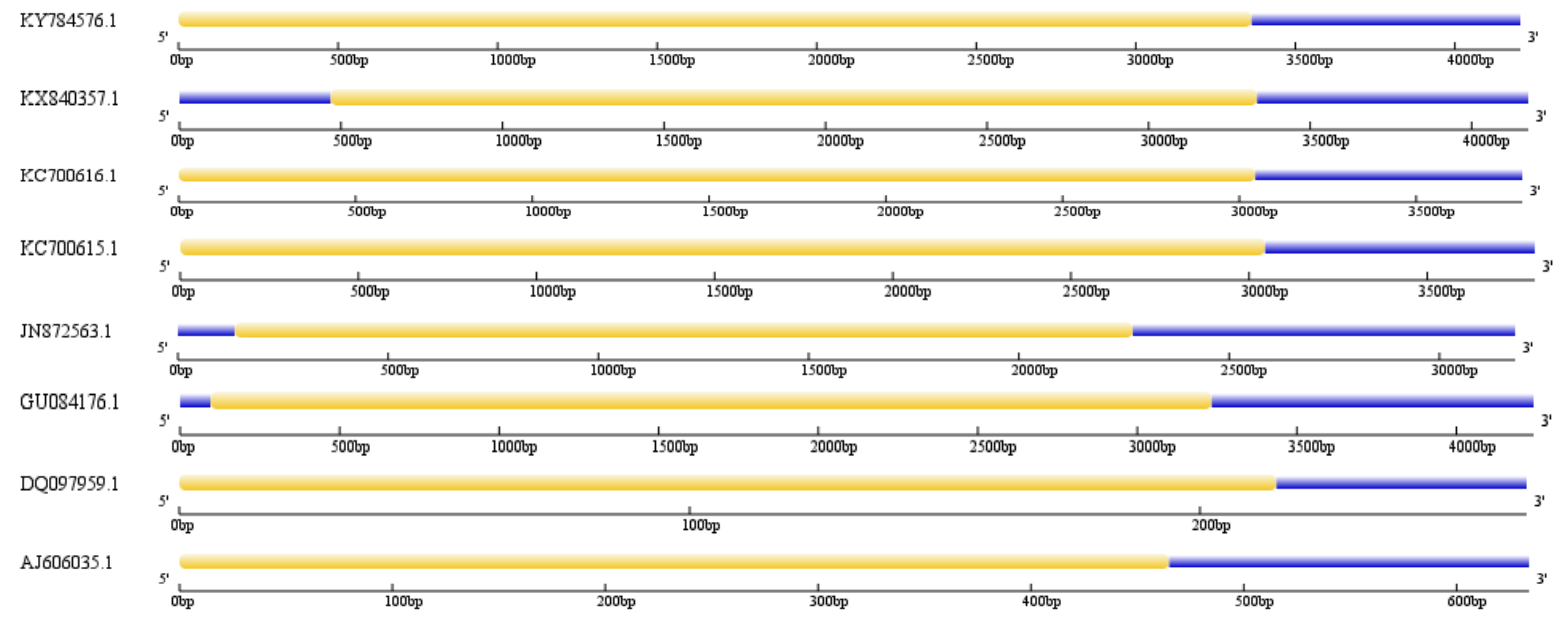

Fig. 4. Exon-intron distribution of protein-encoding LRR accessions. GenBank accessions: KY784576.1, KX840357.1, KC700616.1, KC70015.1, JN872563.1, GUOS4176.1, DQ097959.1, AJ606035.1

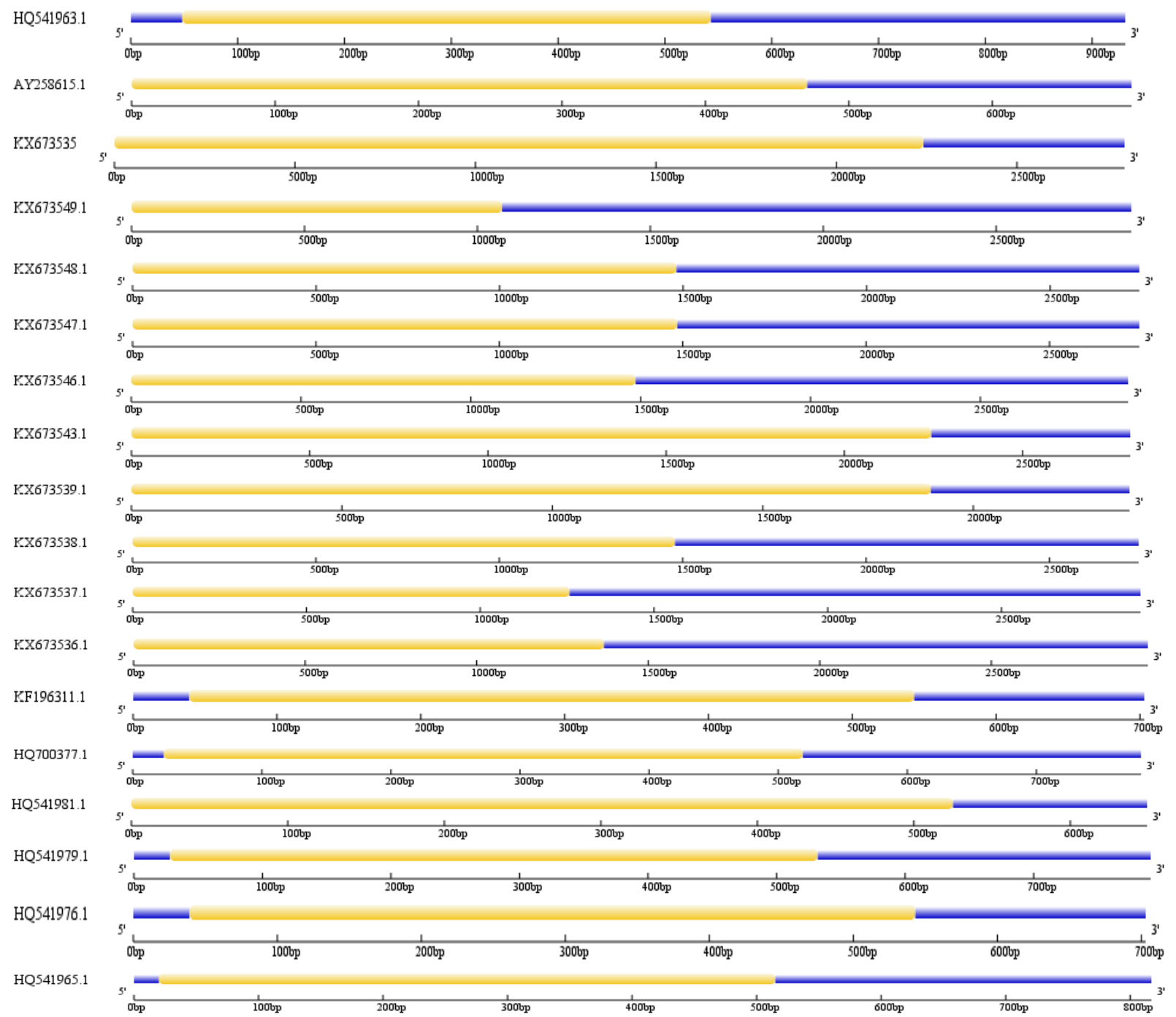

Fig. 5. Exon-intron distribution of accessions encoding pathogenesis protein domain. GenBank accessions: HQ541963.1, AY258615.1, KX673535.1, KX673549.1, KX673548.1, KX673547.1, KX673546.1, KX673543.1, KX673539.1, KX673538.1, KX673537.1, KX673536.1, KF196311.1, HQ700377.1, HQ541981.1, HQ541979.1, HQ541976, HQ541965.1 


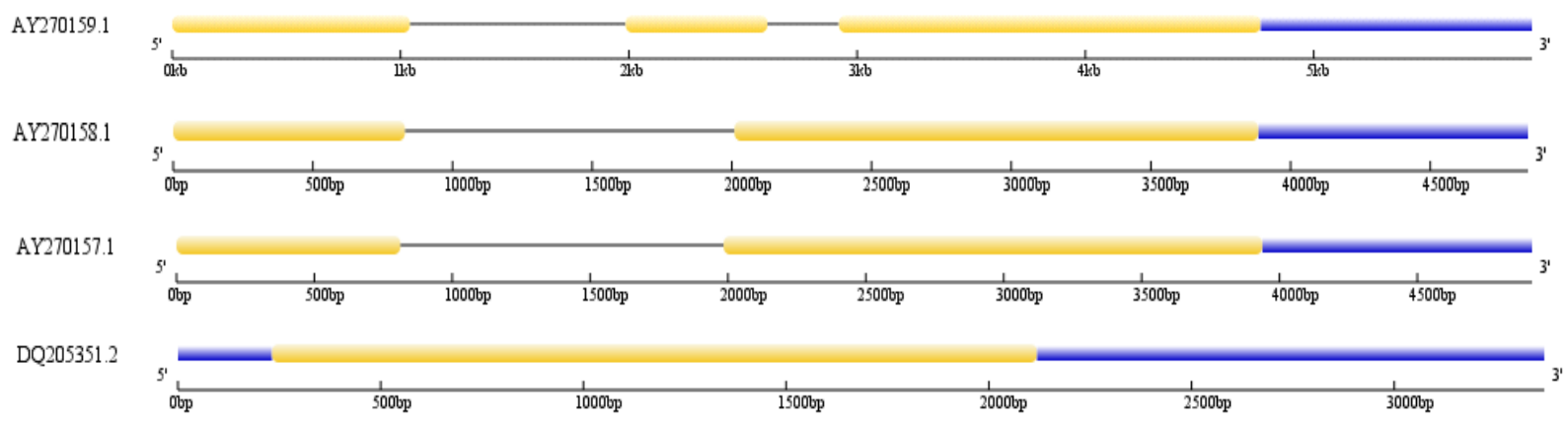

Fig. 6. Exon-intron distribution of resistance protein-encoding accessions. GenBank accessions: AY270159.1, AY270158.1, AY270157.1, DQ205351.2

AY270159.1, AY270158.1, AY270157.1, DQ205351.2 were four disease resistance protein-encoding accessions. Among these four accessions, DQ205351.2 was the smallest (2693 bp) and AY270159.1 was the largest (4768 base pair) (Fig. 6).

The retrieved NBS-LRR, pathogenesis, LRR, resistance protein-encoding accessions could be a potential source of blast resistance. The majority of NBS-LRR protein domains encode resistance genes. The sub-classes of NBS-LRR, CC and TIR have a role in disease resistance (Mchale et al., 2006; Marone et al., 2013). Furthermore, the pathogenesis protein encoding genes have a significant role against stress response by hypersensitive reaction (Van Loon, 1985; Stintzi et al., 1993). So, it can be expected that these retrieved putative protein encoding accessions might be useful for blast resistance in wheat. Further study is needed to identify the role of those protein domain encoding accessions.

\section{Phylogenetic relationship between resistances related protein coding accessions}

The phylogenetic relatedness showed resistance related protein encoding domain of Thatcher (KY064065.1) is related with JP957107.1 with a 0.67 bootstrap value which indicated both accessions had 67\% similarity (Fig. 7). Eighteen putative pathogenesis related protein encoding accessions HQ700377.1, KF196311.1, HQ541979.1, HQ541976.1, HQ541965.1, HQ541963.1, AY258615.1, HQ541981.1, KX673535.1, KX673536.1, KX673537.1, KX673538.1, KX673539.1, KX673543.1, KX673546.1, KX673547.1, KX673548.1, KX673549.1), two putative NBS-LRR protein encoding accessions (KF810140.1, KF810141.1), and two putative LRR protein encoding accessions (KX840357.1, AJ606034.1) were related with rice blast resistant gene Pita (AY196754.1) with 0.72 bootstrap value that showed $72 \%$ similarity (Fig. 7). Phylogenetic analysis was broadly used to find out the closeness of genes and protein domains (Cavalli - sforza and Edwards, 1967; Pan et al., 2000). It is expected that the identified protein encoding accessions of Thatcher and Pita might carry resistance for blast disease. 


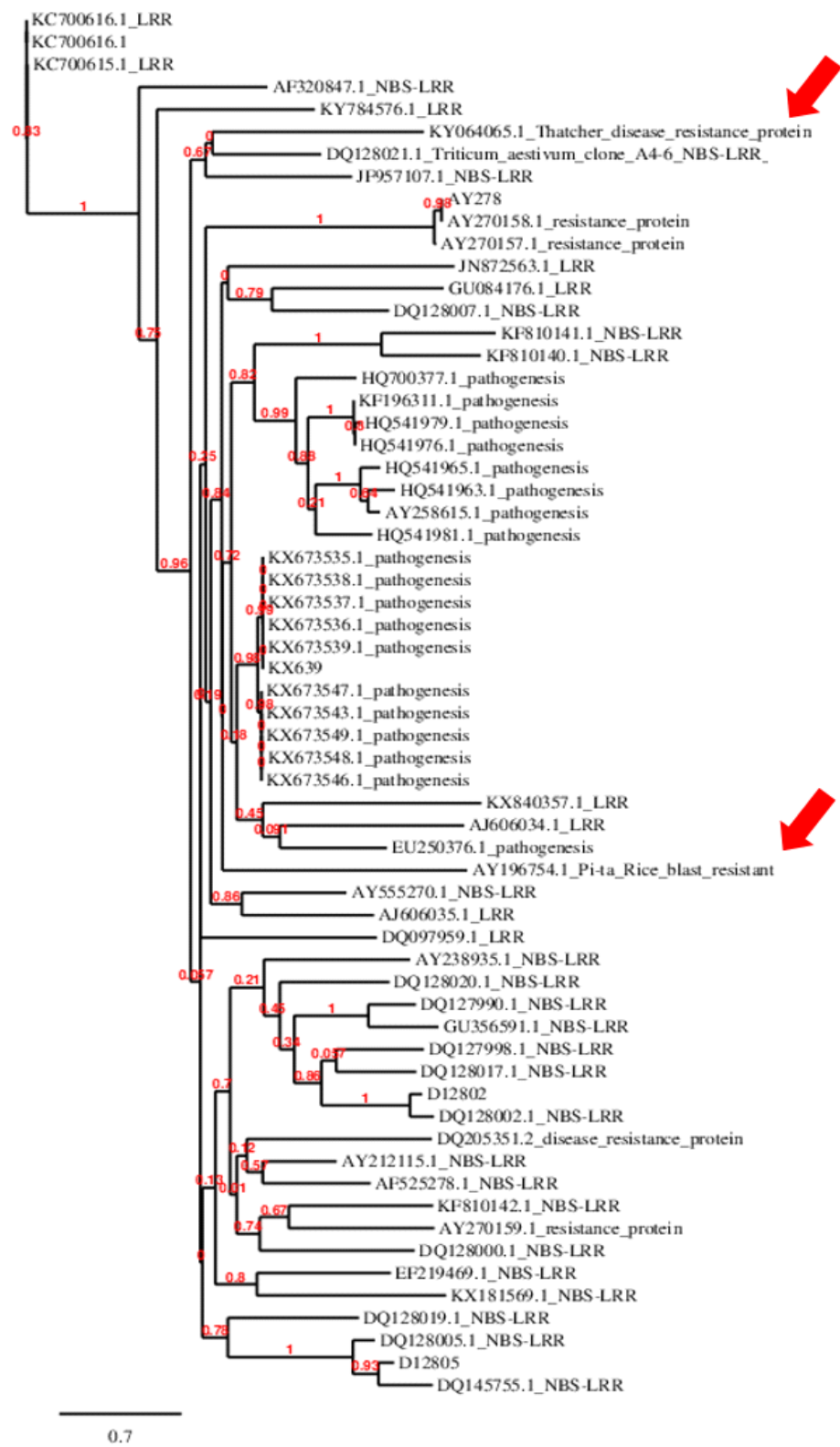

Fig. 7. Phylogenetic tree was constructed using Phylogeny.fr online software. Retrieved putative protein-encoding accessions of wheat genome was utilized for constructing phylogenetic tree where disease resistance protein encoding accession of Thatcher and Pita gene had taken as reference sequence. A NBS-LRR protein encoding accession (JP957107.1) had $67 \%$ similarity with disease resistance protein encoding accession of Thatcher. Likewise, Pita gene had 72\% similarity with 22 protein encoding accessions including 18 pathogenesis, two NBS-LRR and two LRR protein domain-encoding genes.

\section{Phylogenetic relationship among protein domains}

The putative disease resistant protein of Thatcher (AA045168.1) was closely related with two NBS-LRR protein domain (AAZ99757.1, AAZ997575.1) with a 0.78 bootstrap value that showed $78 \%$ similarity (Fig. 8). Disease resistance protein of Thatcher genotype (AR038245.1), two other putative disease resistance proteins (AAQ01784.1, AAQ01785.1) and two putative
NBS-LRR protein domains (AAZ9975.1, AAZ99757.1) were related with Pita protein with 0.43 bootstrap value indicating $43 \%$ similarity (Fig. 8).

So, the closely related proteins of Pita and disease resistance protein of Thatcher might bear resistance for blast. Further study is needed to validate the findings. 


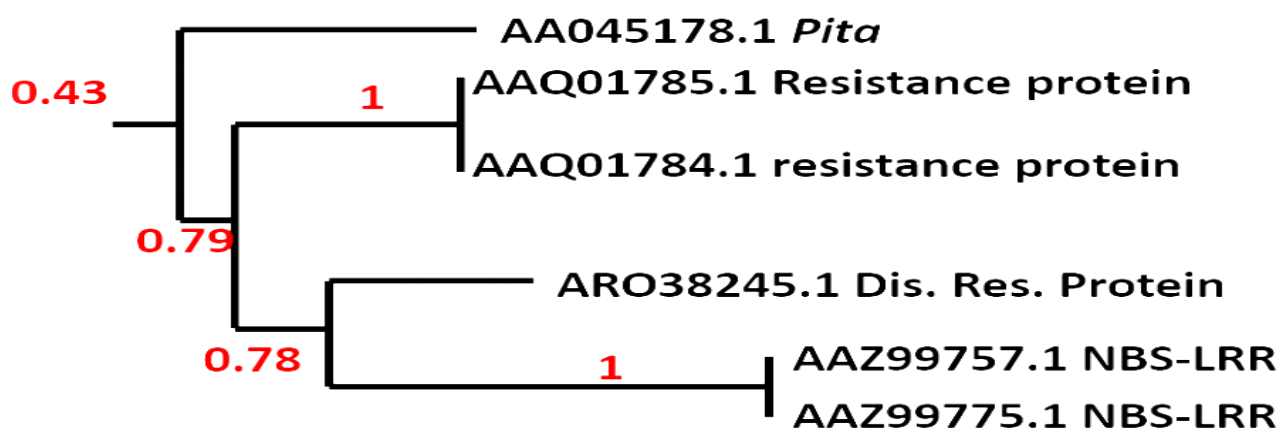

Fig. 8. Phylogenetic tree was constructed using Phylogeny.fr online software. Retrieved putative protein accessions of wheat genome was utilized for constructing phylogenetic tree where disease resistance protein of Thatcher and Pita protein had taken as reference sequence. Pita protein had $43 \%$ similarity with five protein domains including disease resistance protein of Thatcher. Disease resistance protein of Thatcher had $78 \%$ similarity with two NBS-LRR protein domains.

\section{Marker validation}

Eleven markers M2, M3, M4, M5, M6, M7, M11, M13, M14, M16, and M18 respectively amplified genomic DNA of all eighteen wheat genotypes. There was no variation among eighteen genotypes except dark and light DNA bands. The PIC value of all those markers was 0.00. The M1 marker was run for eighteen wheat genotypes and was found to amplify genomic DNA of 14 genotypes except BARI Gom 24, BARI Gom 29, BARI Gom 31 and BARI Gom 32 (Fig. 9). The M8 marker amplified ten genotypes except BARI Gom 31, BARI Gom 32, BARI Gom 33, Sonalika, Protiva, Sourav, Kheri, Kanchan (Fig. 9). The M9 marker amplified genomic DNA of sixteen genotypes except BARI Gom 29 and BARI Gom 30 (Fig. 9). The M10 marker amplified genomic DNA of all genotypes except BARI Gom 29 and BARI Gom 30 (Fig. 9). The M15 marker amplified genomic DNA of all genotypes except BARI Gom 29. M17 marker amplified genomic DNA of all wheat genotypes except BARI Gom 23, BARI Gom 28, BARI Gom 29, BARI Gom 30 and BARI Gom 31 (Fig. 9). Piz3 gene marker amplified genomic DNA of ten genotypes except BARI Gom 21, BARI Gom 23, BARI Gom 27, BARI Gom 28, BARI Gom 29, Sonalika, Protiva, Sourav and Kheri (Fig. 9). M8 and Piz3 markers estimated the highest PIC value of 0.49 .
The PIC values of M1, M9, M10, M12, M15, and M17 markers were $0.35,0.20,0.20,0.24$, and 0.40 respectively.

Previously, NBS-LRR protein domain utilized for the development of rice blast resistant marker and it could be noted that around nineteen NBS-LRR protein encoding accessions were reported as rice blast resistant (Jiang et al., 2012). It has been stated before, BARI Gom 33 is blast resistant wheat genotype in Bangladesh (DGGW, 17; Personal communication, Dr. NCD Barma, Director, BWMRI). BARI Gom 31 and BARI Gom 32 have a moderate level of blast tolerance. BARI Gom 25, BARI Gom 26, BARI Gom 27, BARI Gom 28, BARI Gom 29 and BARI Gom 30 are highly susceptible to wheat blast (DGGW, 2017). The nineteen markers (M1M18, Piz3) were used to differentiate resistant and susceptible genotypes. The electrophoresis image showed that eighteen designed markers M1-M18 and Piz3 amplified both resistant and susceptible genotypes (Data not given; Fig. 9). In 11 markers (M1, M3, M5, M6, M7, M8, M9, M11, M12, M17, and Piz3) both dark and diffused DNA band were present (Data not given; Fig. 9). Dark and diffused DNA band might occur due to InDel or SNP variation (Raghavan et al., 2007). Further study is needed to find out the InDel and SNP variation. 


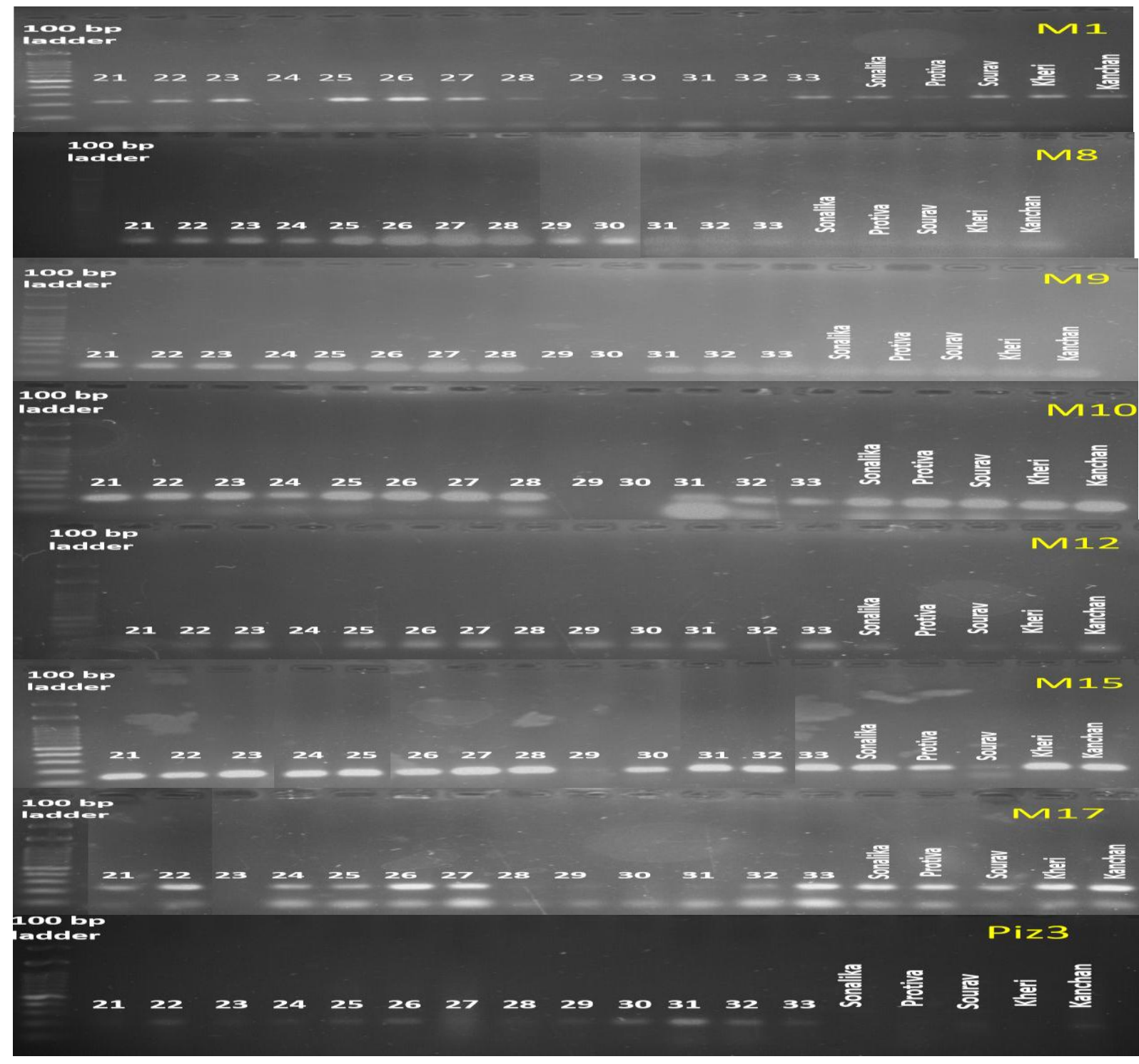

Fig. 9. SSR profile of 18 wheat genotypes respectively, Bari Gom 21, Bari Gom 22, Bari Gom 23, Bari Gom 24, Bari Gom 25, Bari Gom 26, Bari Gom 27, Bari Gom 28, Bari Gom 29, Bari Gom30, Bari Gom 31, Bari Gom 32, Bari Gom 33, Sonalika, Protiva, Sourav, Kheri, Kanchan for M1, M8, M9, M10, M12, M15, M17, and Piz3 markers.

In essence, disease resistance protein-encoding accessions of Thatcher with its paralogs and orthologs of Pita gene might bear blast resistance which should be assessed for blast resistance. The nineteen markers could not distinguish contrasting genotypes as blast resistance SSR marker but the dark and diffused DNA band have to study for Insertion/Deletion and single nucleotide polymorphism which may yield functional markers. New NBS-LRR, pathogenesis, CC, LRR, TIR protein domain encoding accessions could to be utilized for developing wheat blast resistance markers.

\section{References}

Bolser, D., Staines, D.M., Pritchard, E. and Kersey, P., 2016. Ensembl plants: integrating tools for visualizing, mining, and analyzing plant genomics data. In Plant Bioinformatics Humana Press, New York, NY. 115-140. https://doi.org/10.1007/978-1-4939-3167-5_6
Callaway, E., 2016. Devastating wheat fungus appears in Asia for first time. Nature, 532:421-422.https://doi.org/10.1038/532421a

Cavalli - Sforza, L.L. and Edwards, A.W., 1967. Phylogenetic analysis: models and estimation procedures. Evolution, $21: 550-570$.

Couch, B.C. and Kohn, L.M., 2002. A multi locus gene genealogy concordant with host preference indicates segregation of a new species, Magnaporthe oryzae, from $M$. grisea. Mycologia, 94: 683-693.https://doi.org/10.2307/3761719

Cruz, C.D., Peterson, G.L., Bockus, W.W., Kankanala, P., Dubcovsky, J., Jordan, K.W., Akhunov, E., Chumley, F., Baldelomar, F.D. and Valent, B., 2016. The 2NS translocation from Aegilops ventricosa confers resistance to the Triticum pathotype of Magnaporthe oryzae. Crop Science, 56: 9901000.https://doi.org/10.2135/cropsci2015.07.0410

Cruz, M.F.A., Prestes, A.M., Maciel, J.L. and Scheeren, P.L., 2010. Partial resistance to blast on common and synthetic wheat genotypes in seedling and in adult plant growth stages. Tropical Plant Pathology, 35: 24-31. http://dx.doi.org/10.1590/S1982-56762010000100004

Dereeper, A., Guignon, V., Blanc, G., Audic, S., Buffet, S., Chevenet, F. and Claverie, J.M., 2008. Phylogeny. fr: robust 
phylogenetic analysis for the non-specialist. Nucleic Acids Research, 36: W465-W469.

https://doi.org/10.1093/nar/gkn180

DGGW (Delivering Genetic Gain in Wheat) 2017: status and opportunities for wheat seed in India, Bangladesh, Nepal and Bhutan. Borlaug global rust initiative (BGRI). 35.

Goulart, A.C.P. and Paiva, F. de A., 1990. Transmissão de Pyricularia oryzae através de sementes de trigo (Triticum aestivum). Fitopatologia Brasileira, 15:359-362.

Guo, A.Y., Zhu, Q.H., Chen, X. and Luo J.C., 2007. GSDS: a gene structure display server. Hereditas, 29:10231026.https://doi.org/10.1360/yc-007-1023

Igarashi, S., 1986. Pyricularia em trigo. 1. Ocorrencia de Pyricularia sp. noestado do Parana. Fitopatologia Brasileira, 11: 351352.

Imam, J., Alam, S., Mandal, N.P., Variar, M. and Shukla, P., 2014. Molecular screening for identification of blast resistance genes in North East and Eastern Indian rice germplasm (Oryza sativa L.) with PCR based makers. Euphytica, 196 199-211.https://doi.org/10.1007/s10681-013-1024-x

Jiang, N., Li, Z., Wu, J., Wang, Y., Wu. L., Wang. S and Liu, J., 2012. Molecular mapping of the Pi2/9 allelic gene Pi2-2 conferring broad-spectrum resistance to Magnaporthe oryzae in the rice cultivar Jefferson. Rice, 5:29.https://doi.org/10.1186/1939-8433-5-29

Kiyosawa, S., 1982. Genetics and epidemiological modeling of breakdown of plant disease resistance. Annual Review of Phytopathology, 20: 93-117. https://doi.org/10.1146/annurev.py.20.090182.000521

Kohli, M.M., Mehta, Y.R., Guzman, E., De Viedma, L. and Cubilla, L.E., 2011. Pyricularia blast-a threat to wheat cultivation. Czech Journal of Genetics and Plant Breeding, 47:130134.https://doi.org/10.17221/3267-CJGPB

Laila, R., Park, J.I., Robin, A.H.K., Natarajan, S., Vijayakumar, H., Shirasawa, K., Isobe, S., Kim, H.T. and Nou, I.S., 2019. Mapping of a novel clubroot resistance QTL using ddRADseq in Chinese cabbage (Brassica rapa L.). BMC Plant Biology, 19:13.https://doi.org/10.1186/s12870-018-1615-8

Leach, J. E., Vera, C. M., Bai, J. and Leung, H., 2001. Pathogen fitness penalty as a predictor of durability of disease resistance genes. Annual Review of Phytopathology 39, 187224.https://doi.org/10.1146/annurev.phyto.39.1.187

Malaker, P.K., Barma, N.C., Tiwari, T.P., Collis, W.J., Duveiller, E., Singh, P.K., Joshi, A.K., Singh, R.P., Braun, H.J. and Peterson, G.L., 2016. First report of wheat blast caused by Magnaporthe oryzae pathotype triticum in Bangladesh. Plant Disease, 100:2330-2330. https://dx.doi.org/10.5423\%2FPPJ.RW.09.2016.0179

Marone, D., Russo, M., Laidò, G., De Leonardis, A. and Mastrangelo, A., 2013. Plant nucleotide binding site-leucine-rich repeat (NBS-LRR) genes: active guardians in host defense responses. International Journal of Molecular Sciences, 14:7302-7326. https://doi.org/10.3390/ijms14047302
McHale, L., Tan, X., Koehl, P. and Michelmore, R.W., 2006. Plant NBS-LRR proteins: adaptable guards. Genome Biology, 7:212.https://dx.doi.org/10.1186\%2Fgb-2006-7-4212

Pan, Q., Wendel, J. and Fluhr, R., 2000. Divergent evolution of plant NBS-LRR resistance gene homologues in dicot and cereal genomes. Journal of Molecular Evolution. 50:203-213.

Prestes, A.M., Arendt, P.F., Fernandes, J.M.C. and Scheeren, P.L., 2007. Wheat production in stressed environments. Springer, Dordrecht, pp.119-123. https://doi.org/10.1007/1-40205497-1_16

Pruitt, K.D., Tatusova, T. and Maglott, D.R., 2005. NCBI Reference Sequence (RefSeq): a curated non-redundant sequence database of genomes, transcripts and proteins. Nucleic Acids Research, 33:D501-D504 .https://doi.org/10.1093/nar/gki025

Raghavan, C., Naredo, M.E.B., Wang, H., Atienza, G., Liu, B., Qiu, F. and Leung, H., 2007. Rapid method for detecting SNPs on agarose gels and its application in candidate gene mapping. Molecular Breeding, 19:87-101. https://doi.org/10.1007/s11032-006-9046-x

Stintzi, A., Heitz T., Prasad, V., Wiedemann-Merdinoglu, S., Kauffmann, S., Geoffroy, P. and Fritig, B., 1993. Plant 'pathogenesis-related' proteins and their role in defense against pathogens. Biochimie, 75:687-706.

Untergasser, A., Nijveen, H., Rao, X., Bisseling, T., Geurts, R. and Leunissen, L.A., 2007. Primer3Plus, an enhanced web interface to Primer3. Nucleic Acids Research, 35: W71W74.https://doi.org/10.1093/nar/gkm306

Urashima, A.S., Lavorent, N.A., Goulart, A.C. and Mehta, Y.R., 2004. Resistance spectra of wheat cultivars and virulence diversity of Magnaporthe grisea isolates in Brazil. Fitopatologia Brasileira, 29:511-518. http://dx.doi.org/10.1590/S0100-41582004000500007

Van Loon, L.C., 1985. Pathogenesis-related proteins. Plant Molecular Biology, 4:111-116.https://doi.org/10.1007/BF02418757

Wang, H.Y., Liu, D.Q. and Yang, W.X., 2011. A wheat disease resistance gene analog of the NBS-LRR class: identification and analysis. Journal of Plant Diseases and Protection, 118:63-68.https://doi.org/10.1007/BF03356383

Ware, D., Jaiswal, P., Ni, J., Pan, X., Chang, K., Clark, K. and McCouch, S., 2002. Gramene: a resource for comparative grass genomics. Nucleic Acids Research, 30:103-105. https://doi.org/10.1104/pp.015248

Zhan, S.W., Mayama, S. and Tosa, Y. 2007. Identification of two genes for resistance to Triticum isolates of Magnaporthe oryzae in wheat. Genome, 51:216-221. https://doi.org/10.1139/G07-094

Zhang, X.C. and Gassmann, W., 2007. Alternative splicing and mRNA levels of the disease resistance gene RPS4 are induced during defense responses. Plant Physiology, 145:15771587. https://doi.org/10.1104/pp.107.108720 